Article

\title{
Au Doping ZnO Nanosheets Sensing Properties of Ethanol Gas Prepared on MEMS Device
}

\author{
Yempati Nagarjuna and Yu-Jen Hsiao * \\ Department of Mechanical Engineering, Southern Taiwan University of Science and Technology, Tainan 710, \\ Taiwan; arjunrocky786@gmail.com \\ * Correspondence: yujen@stust.edu.tw; Tel.: +886-6-2533131 (ext. 3542)
}

Received: 31 August 2020; Accepted: 28 September 2020; Published: 30 September 2020

\begin{abstract}
Sensitivity of the Micro Electro Mechanical System (MEMS) device ZnO nanosheets sensor and the $\mathrm{Au}$ doped $\mathrm{ZnO}$ nanosheets sensor has been investigated. The $\mathrm{ZnO}$ samples have been prepared using Hydrothermal synthesis at $90{ }^{\circ} \mathrm{C}$. The prepared $\mathrm{ZnO}$ nanostructure is tested for structural morphology and crystallinity properties. The elemental analysis of the $\mathrm{ZnO}$ sample and $\mathrm{Au}-\mathrm{ZnO}$ samples are tested by using Energy Dispersive X-ray Spectroscopy (EDS) spectrum analysis. MEMS device microheater is designed and prepared for testing the sensitivity of Ethanol gas. Thermal properties of the MEMS microheater is studied for better gas testing at different temperatures. Both the $\mathrm{ZnO}$ nanosheets sensor and $\mathrm{Au}$ doped $\mathrm{ZnO}$ nanosheets sensor are tested using Ethanol gas, and the gas concentrations are taken to be $15,30,45$, and $60 \mathrm{ppm}$ at $300^{\circ} \mathrm{C}$. The gas sensing response of pure $\mathrm{ZnO}$ nanosheets tested for ethanol gas at $60 \mathrm{ppm}$ showed $20 \%$, while the $\mathrm{Au}-\mathrm{ZnO}$ nanosheets showed $35 \%$, which is increased by $15 \%$ at similar operating conditions.
\end{abstract}

Keywords: MEMS device; $\mathrm{ZnO}$ nanosheets; Au doped $\mathrm{ZnO}$; hydrothermal synthesis; gas sensitivity

\section{Introduction}

Semiconductor gas sensors are widely used in today's scenario for the detection of harmful and poisonous gases. Among the different kinds of sensors used for gas detection are resistive gas sensors [1], capacitive gas sensors [2], and electrochemical sensors [3], while most of the ongoing studies are concentrating on semiconductor gas sensors. This kind of gas sensor utilizes the porous sintered material body which comprises of polycrystalline particles of the metal oxide used for the gas sensor [4]. Nowadays, semiconductor gas sensors are widely used in many industries and public homes as gas leak detectors and alarms. Usually, any gas sensors have mainly two basic functions: (i) the recognition of the objective gas to that of the other gases, which is a function of the receptor, and (ii) to transduce the recognized gas to a concentration dependent output signal [5]. So, in the case of semiconductor gas sensors, function of the receptor is provided by the objective gas interaction with the semiconductor material and surface adsorption of the objective gas on the surface of the semiconductor. Function of the transducer is dependent on the metal oxide band structure and also on the coagulated structure of microparticles [6].

Most research studies consider metal oxides semiconductors as the sensing materials for developing gas sensors. There are different kinds of metal oxides for gas detections like $\mathrm{ZnO}$ [7], $\mathrm{SnO}_{2}$ [8], $\mathrm{In}_{2} \mathrm{O}_{3}$ [9], $\mathrm{Fe}_{2} \mathrm{O}_{3}$ [10], and $\mathrm{TiO}_{2}$ [11]. Among these metal oxides, $\mathrm{ZnO}$ thin films are considered mostly for developing the gas sensor $[12,13]$. The main reason is due to the easy availability and easy deposition methods. $\mathrm{ZnO}$ is an n-type semiconductor that is thermally and chemically stable. $\mathrm{ZnO}$ has large bandgap energy $(3.37 \mathrm{eV})$ and large excitation binding energy $(60 \mathrm{meV})$ [14]. $\mathrm{ZnO}$ is a promising semiconductor metal oxide due to numerous applications such as gas sensors, surface acoustic wave (SAW) devices, electrodes, etc. For the deposition process, there are so many different types 
of techniques for the doped and undoped deposition processes. Some of the processes include hydrothermal synthesis, sol-gel process, sputtering, PECVD, dip coating, etc. [15]. Different types of $\mathrm{ZnO}$ nanostructures like $\mathrm{ZnO}$ nanorods, $\mathrm{ZnO}$ nanowires, $\mathrm{ZnO}$ nanoflowers, etc., are prepared for the gas sensing processes. Most of these preparation processes use Solid-Liquid-Vapor (SLV) technique and thermal evaporation techniques which require temperatures of more than $900{ }^{\circ} \mathrm{C}[16,17]$. The current study uses Hydrothermal synthesis of $\mathrm{ZnO}$ deposition, in which $\mathrm{ZnO}$ can be successfully synthesized at $90{ }^{\circ} \mathrm{C}$. Hydrothermal synthesis is a one-step synthetic procedure and is an environmentally friendly process. From recent studies, metal oxide semiconductor sensitivity can be enhanced with the addition of noble metals as a doping agent [18], as well as the deposition of bi-layered or double layered metal oxides [19]. Metal doping has proven to be an important factor in enhancing the gas sensing response, as these doping agents change the band energy structure, changing the morphology and increasing the surface-to-volume ratio for more gas interaction [20]. In the current study, Gold (Au) doping is chosen. The band gap of Au doped $\mathrm{ZnO}$ has proven to be lower than bare $\mathrm{ZnO}$, which shows $\mathrm{Au}$ doped $\mathrm{ZnO}$ is more electrically active than bare $\mathrm{ZnO}$ due to the availability of more free electrons as donors [21]. $\mathrm{Li}$ [22] revealed that the doping of $\mathrm{ZnO}$ with $\mathrm{Au}$ and $\mathrm{Y}$ elements has increased the sensing response of acetone substantially when compared to bare $\mathrm{ZnO}$ and $\mathrm{Au}-\mathrm{ZnO}$, which are prepared by the facile wet chemical method. Lai [23] used the electrospinning process to develop combined nanostructures of $\mathrm{ZnO}$ and $\mathrm{SnO}_{2}$ along with Au doping, proving the improved gas sensing response of ethanol. Huang [24] developed the $\mathrm{ZnO}$ sensor with 2 metal dopants like $\mathrm{Au}$ and $\mathrm{Pd}$, which can detect the ppb levels of acetone gas with enhanced sensitivity. It is clear that the noble metal dopants can enhance the sensing properties of semiconductors with different preparation methods.

In this study, Ethanol gas was chosen to test the sensitivity of the gas sensor. Volatile Organic Compound (VOC) gases are attracting many researchers for their harmful nature and wide variety of gases. These gases have to be monitored for environmental safety and public safety. Ethanol gas is one of the most important and common VOC gases that needs to be detected during leakage, or in the case of a drunk driving test [25]. Most of the ethanol gas detection sensors are coated with metal oxide semiconductors due to advantages like easy availability, non-toxic, high sensitivity, and being a stable compound.

The current study implemented the hydrothermal synthesis for the deposition of doped $\mathrm{ZnO}$ with $\mathrm{Au}$ noble metals. The study was conducted to compare the gas sensing response of the $\mathrm{ZnO}$ sensor to that of the Au doped $\mathrm{ZnO}$ sensor. As mentioned, the detection gas was chosen to be ethanol gas. The maximum gas concentration was chosen to be $60 \mathrm{ppm}$ in order to prepare a gas sensor to have maximum sensing response with low gas concentrations.

\section{Materials and Methods}

Hydrothermal synthesis is the process chosen for the deposition of $\mathrm{ZnO}$ nanostructure. The primary materials for the formation of $\mathrm{ZnO}$ are $\mathrm{Zinc}$ nitrate hexahydrate $\left(\mathrm{Zn}\left(\mathrm{NO}_{3}\right)_{2} \cdot 6 \mathrm{H}_{2} \mathrm{O}\right)$ and Hexamethylenetetramine (HMTA/ $\mathrm{C}_{6} \mathrm{H}_{12} \mathrm{~N}_{4}$ ). In aqueous solutions containing $0.06 \mathrm{M}$ of each $\mathrm{Zn}\left(\mathrm{NO}_{3}\right)_{2} \cdot 6 \mathrm{H}_{2} \mathrm{O}$ and HMTA are taken in a laboratory bottle. Thin films and the MEMS microheater (Taiwan Semiconductor Research Institute (TSRI), Tainan city, Taiwan) in which the ZnO structure has to deposit, have to be placed inside the bottle. The prepared bottle is placed in a heating oven at $90^{\circ} \mathrm{C}$ with the time set at $90 \mathrm{~min}$. After the designated time, the $\mathrm{ZnO}$ nanostructure is deposited over the thin film, and the same process is repeated for the deposition of $\mathrm{ZnO}$ nanostructure on MEMS microheater. For the case of Au doping, Gold (III) chloride trihydrate $\left(\mathrm{HAuCl}_{4} \cdot 3 \mathrm{H}_{2} \mathrm{O}\right)$ solution is added to the mixture of $\mathrm{Zn}\left(\mathrm{NO}_{3}\right)_{2} \cdot 6 \mathrm{H}_{2} \mathrm{O}$ and the HMTA solution in a laboratory bottle. $0.0018 \mathrm{M}$ of Au solution is considered for the doping. The entire process of hydrothermal synthesis is shown in Figure 1. After the $\mathrm{ZnO}$ and $\mathrm{Au}$ doped $\mathrm{ZnO}$ deposited on the microheater, the samples were annealed at $500{ }^{\circ} \mathrm{C}$ temperature using a Rapid Thermal Annealing (RTA) machine (Premtek, Hsinchu city, Taiwan). 


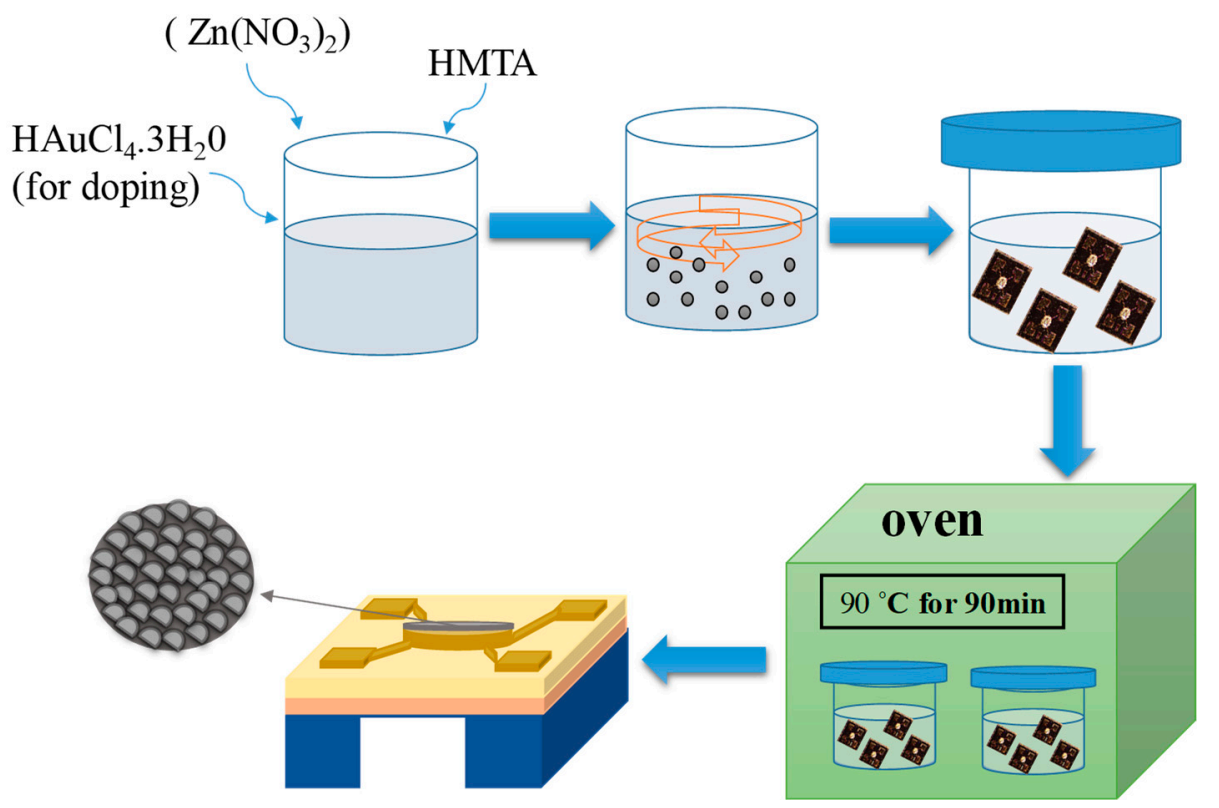

Figure 1. Hydrothermal process of $\mathrm{ZnO}$ nanosheet deposition.

MEMS microheater is one of the important devices in gas sensing. For the current study, a MEMS microheater is designed in CAD 2D software (2012 version) and fabricated by semiconductor processes. The device dimensions are of $3700 \times 3700 \mu \mathrm{m}^{2}$ from electrode to electrode, and the sensing area dimension is $800 \times 800 \mu \mathrm{m}^{2}$. The outline of the fabricated microheater is shown in Figure 2a. The $\mathrm{ZnO}$ nanosheets deposited the sensing area with microheater is shown in Figure $2 \mathrm{~b}$. The four electrodes of microheater are made of Gold ( $\mathrm{Au}$ ) and Titanium (Ti), which are deposited using a Electron Gun machine. The resistance readings of the microheater without $\mathrm{ZnO}$ deposition and deposited $\mathrm{ZnO}$ are almost similar.

(a)

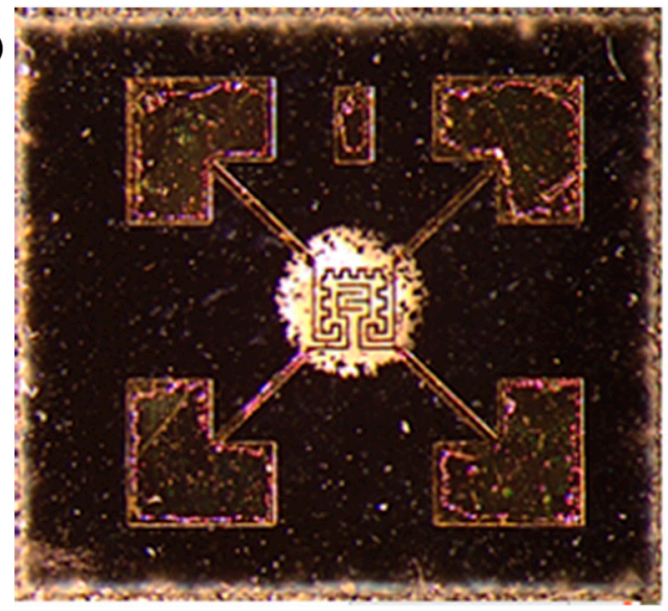

(b)

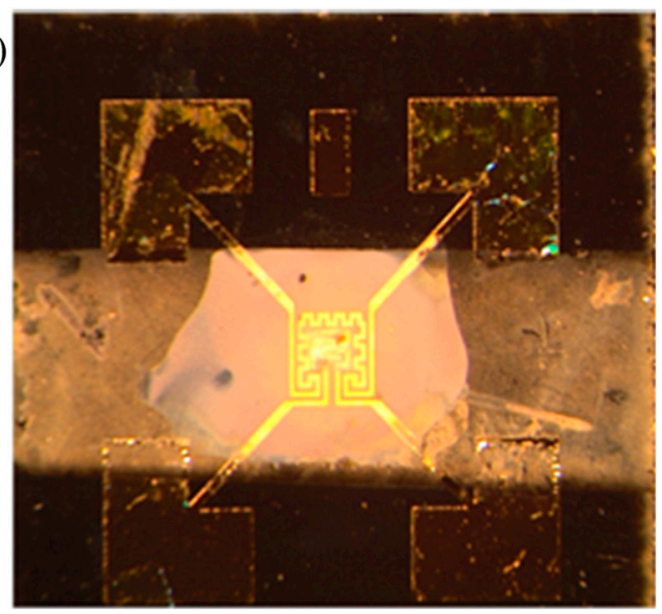

Figure 2. (a) Fabricated Micro Electro Mechanical System (MEMS) microheater and (b) ZnO nanosheets deposited microheater.

The ethanol gas is diluted to $15-60 \mathrm{ppm}$ from a $2300 \mathrm{ppm}$ ethanol gas cylinder. The sample was placed in the chamber and then heated at $300{ }^{\circ} \mathrm{C}$ for $60 \mathrm{~s}$ in an air ambient atmosphere to form a stable resistance. Notably, the sealed chamber had an inlet port connected to a gas inlet valve, and an outlet port connected to an air pump. During the gas-sensing measurements, the outlet port is closed and ethanol gas is injected into the chamber through a gas-injecting syringe. In this stage, the resistivity of the sample was measured continuously in the presence of ethanol gas and air. After the chamber was 
stabilized, the outlet port was opened so that the chamber could eliminate the ethanol gas. At this point, the inlet valve was opened simultaneously to introduce air into the chamber. This can form a dynamic curve of the gas measurement.

\section{Results \& Discussion}

Figure 3 shows the XRD (Bruker, Hsinchu city, Taiwan) graph analysis of the $\mathrm{ZnO}$ sample. The samples are being heated at three different temperatures 400,500 , and $600{ }^{\circ} \mathrm{C}$, respectively. All the samples were annealed using a Rapid Thermal Annealing (RTA) machine. With the increase in the temperatures, the $\mathrm{ZnO}$ peaks such as (100), (002), (101), (110), and (103) showed great improvement in the crystalline process. The XRD result of $\mathrm{ZnO}$ structure is in accordance to the $\mathrm{ZnO}$ JCPDS: 36-1451 structure.

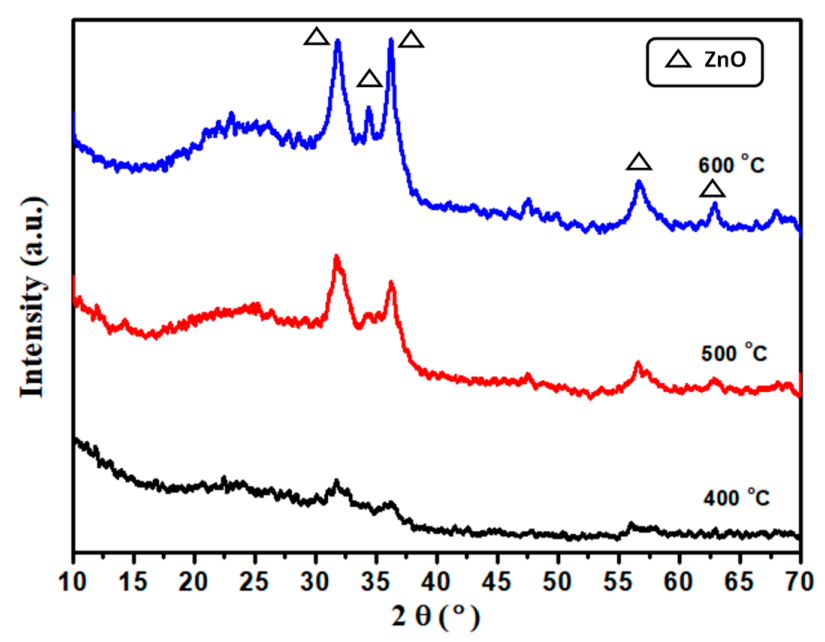

Figure 3. XRD analysis of $\mathrm{ZnO}$ samples.

Figure 4 shows the XRD analysis of the Au doped $\mathrm{ZnO}$ sample. The figure represents the XRD graph $\mathrm{Au}-\mathrm{ZnO}$ samples heated at different temperatures. The samples were heated at 400, 500, and $600^{\circ} \mathrm{C}$ using a Rapid Thermal Annealing (RTA) machine. Similar to ZnO samples, Au doped ZnO samples with Au peaks (111) and (200) also showed good crystallinity improvement with the increase in temperature. The Au peaks in the graph is in accordance with the Au JCPDS 65-8601 structure.

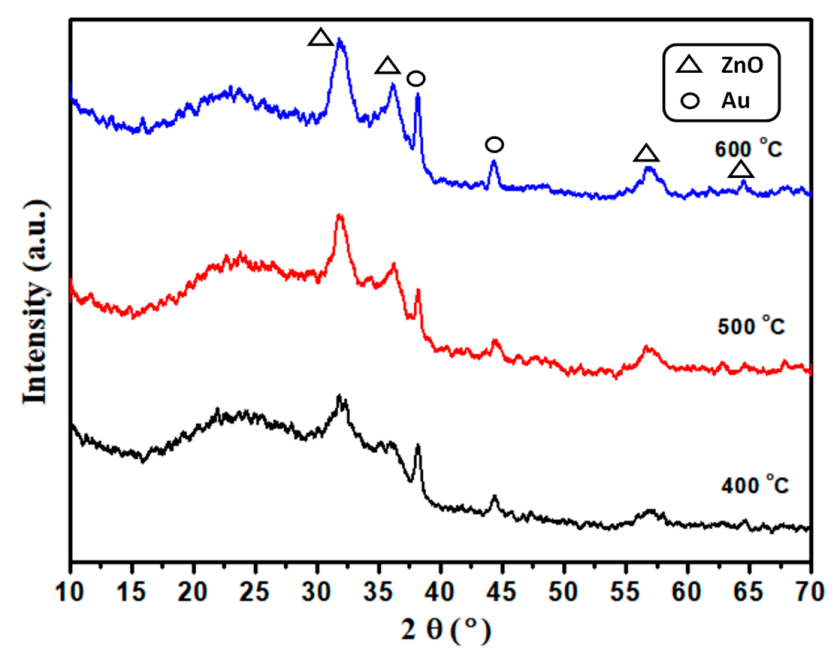

Figure 4. XRD analysis of Au doped $\mathrm{ZnO}$ samples. 
Figure 5 a shows the SEM image of the $\mathrm{ZnO}$ sample annealed at $500^{\circ} \mathrm{C}$. The hydrothermal synthesis preparation of the sample provided good deposition of $\mathrm{ZnO}$ material all over the surface. The structure of the sample reminds one of a spider web type of structure. Figure $5 \mathrm{~b}$ shows the SEM image of the $\mathrm{Au}$ doped $\mathrm{ZnO}$ sample, which is also annealed at $500{ }^{\circ} \mathrm{C}$. Similar to the $\mathrm{ZnO}$ sample, the $\mathrm{Au}-\mathrm{ZnO}$ sample also had a good deposition all over the surface. The Au dopant mixed with the $\mathrm{ZnO}$ solution formed $\mathrm{ZnO}$ nanorods upon heating during the hydrothermal synthesis. The $\mathrm{ZnO}$ nanorods are not to be seen in the pure $\mathrm{ZnO}$ sample is the indication of the formation of $\mathrm{ZnO}$ nanorods with $\mathrm{Au}$ doping. The structure of the Au doped $\mathrm{ZnO}$ is also looks like a spider web structure, but there is a shrinking among the pores which differentiates the structure between pure $\mathrm{ZnO}$ and $\mathrm{Au}$ doped $\mathrm{ZnO}$ samples. The pores present on both the samples will be good for the gas detection to absorb the incoming gas.

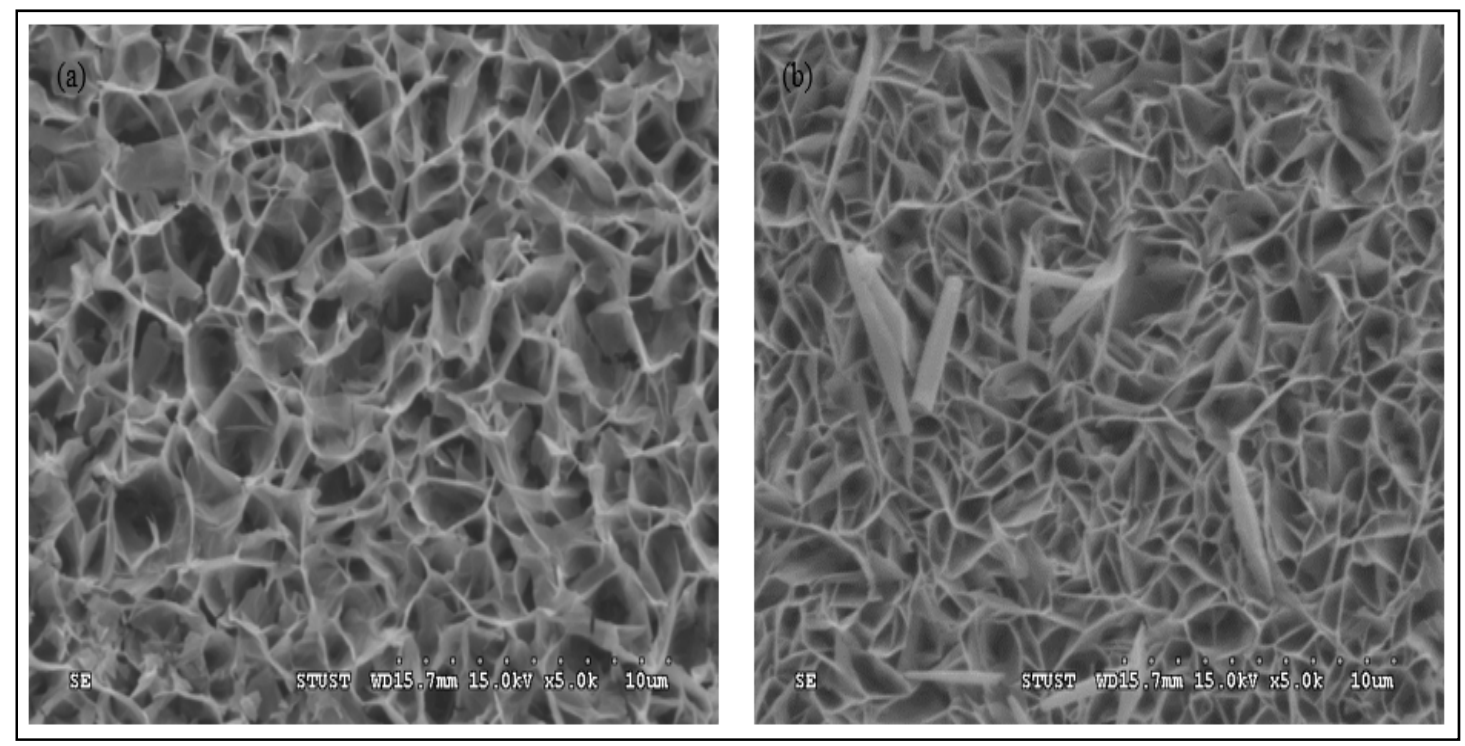

Figure 5. SEM image of (a) $\mathrm{ZnO}$ sample and (b) $\mathrm{Au}-\mathrm{ZnO}$ sample.

TEM analysis of the $\mathrm{ZnO}$ sample heated at $500{ }^{\circ} \mathrm{C}$ is shown in Figure 6a. The $\mathrm{ZnO}$ sample from the figure is a solid structure with rough edges. While the Au doped $\mathrm{ZnO}$ sample has a different structural surface, which is shown in Figure $6 \mathrm{~b}$, the $\mathrm{Au}-\mathrm{ZnO}$ sample has smooth surface over the top and around the edges. The presence of $\mathrm{Au}$ is also spotted as a black mark which is spherical and homogenous, as mentioned in the figure.

The SAED pattern for the Au doped $\mathrm{ZnO}$ is shown in Figure 6c. The crystalline rings of the Au sample can be seen clearly, which proves the improvement of its crystalline nature in the XRD analysis. The elemental analysis of the $\mathrm{Au}-\mathrm{ZnO}$ sample is shown in Figure 6d. Oxygen has more atomic weight presence in the sample, which is $49.58 \%$ and followed by the Zinc, which has an atomic weight of $23.17 \%$. The doping agent $\mathrm{Au}$ has $9 \%$ atomic weight presence.

Power vs. Temperature graph of the microheater according to the Voltage ampere values are shown in Figure 7. The graph is linear, showing the constant increase of the power consumption. At $36.01 \mathrm{~mW}$, the temperature of the microheater is $100{ }^{\circ} \mathrm{C}$ and at $144.21 \mathrm{~mW}$, the temperature of the microheater reaches a maximum level of $300{ }^{\circ} \mathrm{C}$. Insight pictures show the thermal images of the microheater at 100 and $300{ }^{\circ} \mathrm{C}$. Thermal readings scale of the microheater is shown in the inset figures, which shows the temperatures of microheater at different positions. At 100 and $300{ }^{\circ} \mathrm{C}$, the temperatures of the microheater at the electrodes are recorded and shown. The microheater data is calculated with five different samples and the values of voltage, current, resistance, and power consumption are taken as an average value. The voltage and current readings are $7.2 \mathrm{~V}$ and $0.2 \mathrm{~mA}$, and the resistance value can be obtained from $V-I$ readings, which is $350 \mathrm{ohms}$. The power consumption of the microheater at mentioned $V-I$ values is $144 \mathrm{~mW}$ and the temperature is set at $300{ }^{\circ} \mathrm{C}$. 

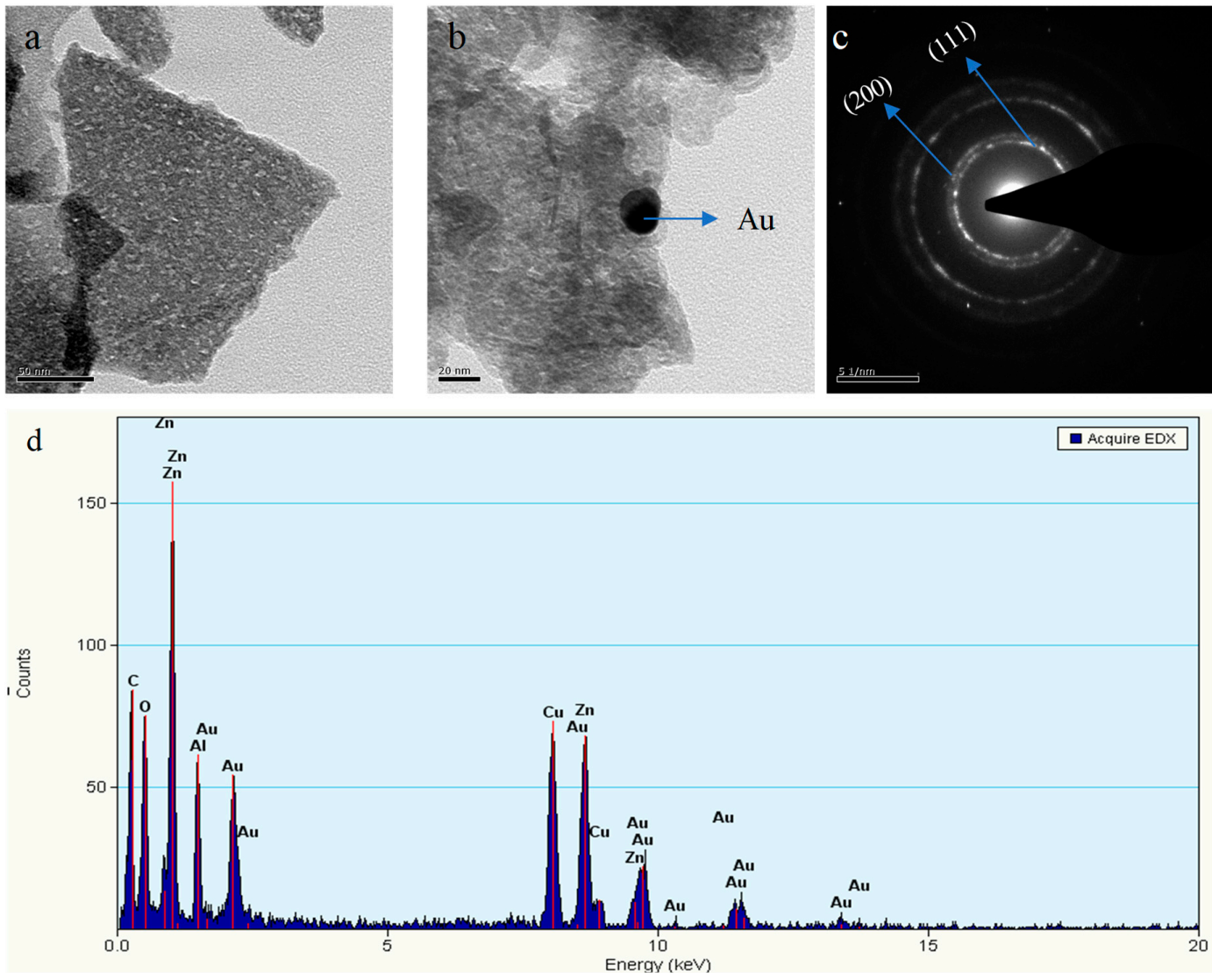

Figure 6. (a) TEM analysis of $\mathrm{ZnO}$ sample and (b) Au-ZnO sample, (c) SAED pattern for Au- $\mathrm{ZnO}$ sample and (d) Elemental analysis of $\mathrm{Au}-\mathrm{ZnO}$ sample.

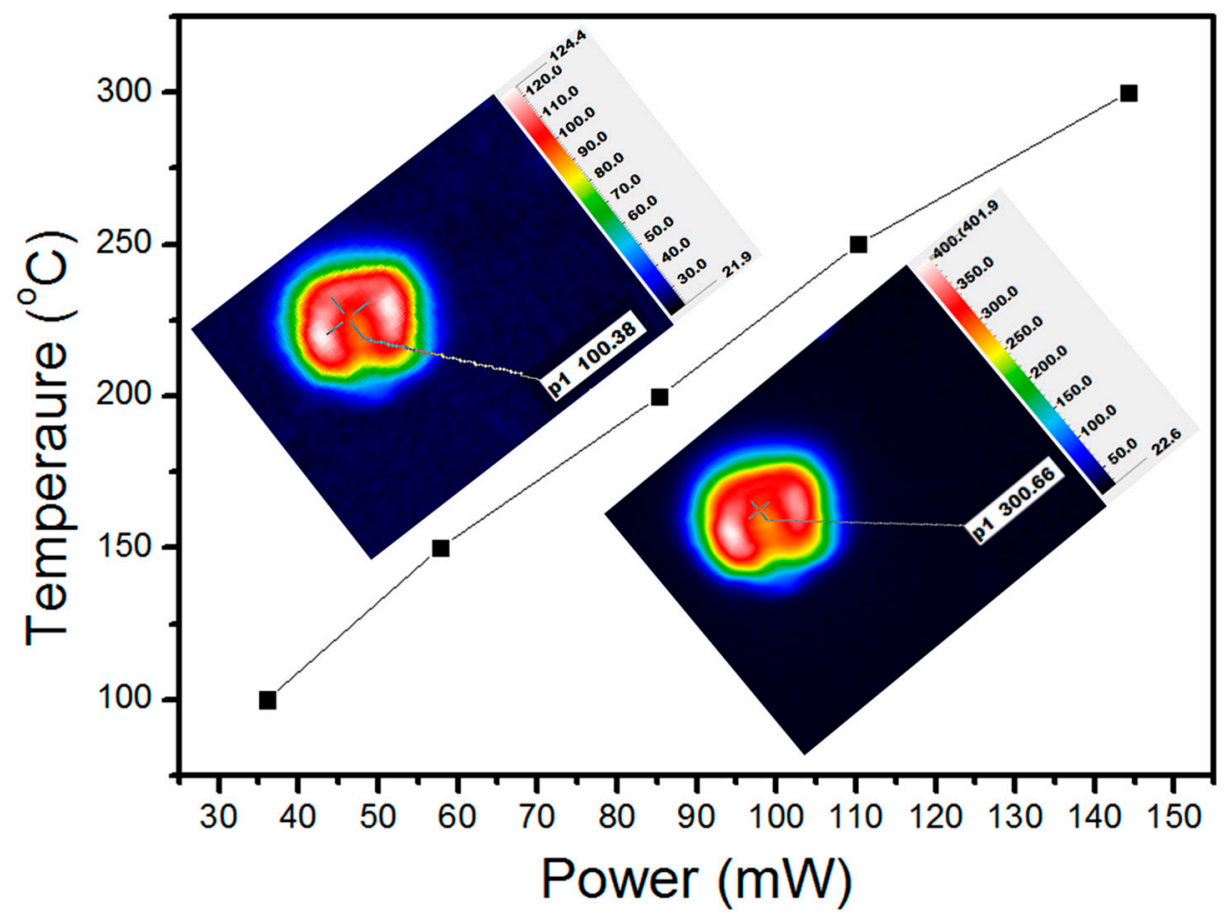

Figure 7. Power vs. Temperature graph of MEMS microheater.

The sensing properties of $\mathrm{ZnO}$ sample annealed at $500{ }^{\circ} \mathrm{C}$ is shown in Figure 8a. Gas sensing measurements were taken at $133 \mathrm{~mW}$ power consumption which is at $300^{\circ} \mathrm{C}$. The gas concentrations are 
taken from $15 \mathrm{ppm}$ to $60 \mathrm{ppm}$ with an increasing level of $15 \mathrm{ppm}$. At $15 \mathrm{ppm}$ Ethanol gas concentration, $\mathrm{ZnO}$ sensor showed $5 \%$ of sensing response and at $60 \mathrm{ppm}$, the sensing response is recorded to be $20 \%$.
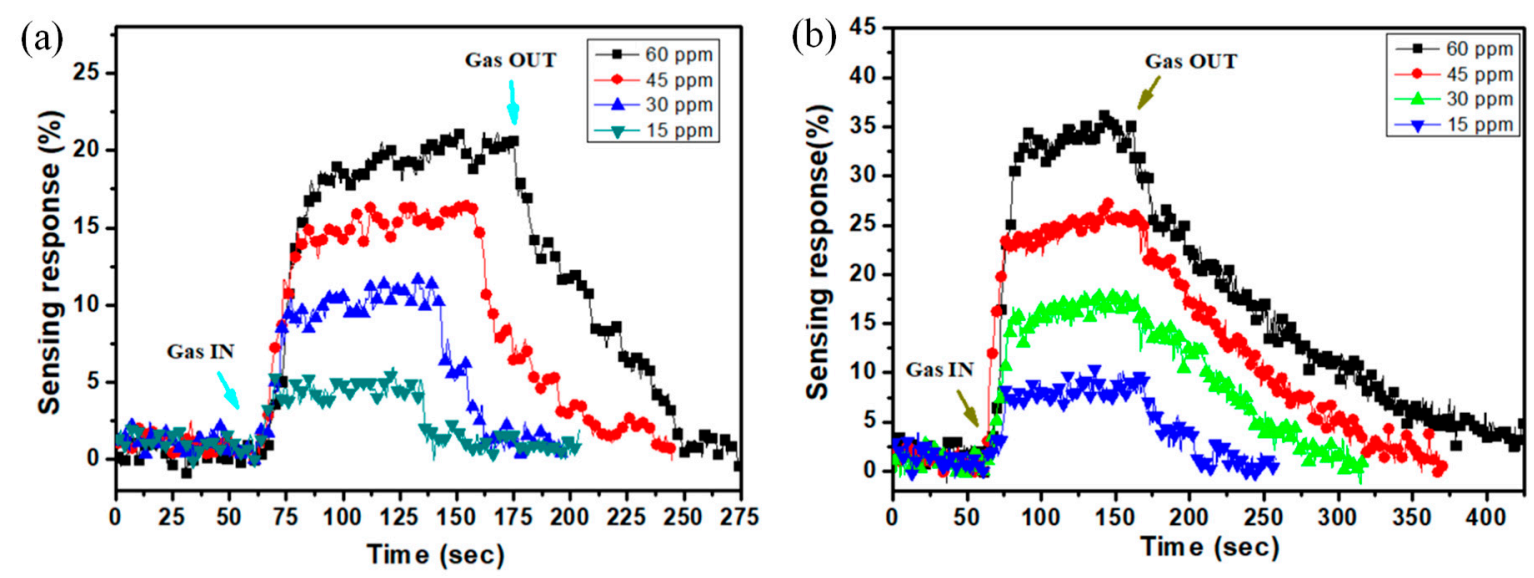

Figure 8. (a) Sensing response of $\mathrm{ZnO}$ sample sensor and (b) $\mathrm{Au}-\mathrm{ZnO}$ sample sensor.

The sensing properties of $\mathrm{Au}-\mathrm{ZnO}$ sample annealed at $500{ }^{\circ} \mathrm{C}$ is shown in Figure $8 \mathrm{~b}$. The power consumption and temperature variables are the same as the $\mathrm{ZnO}$ sample, which are $133 \mathrm{~mW}$ and 300 ${ }^{\circ} \mathrm{C}$. At $15 \mathrm{ppm}$ Ethanol gas concentration, the $\mathrm{Au}-\mathrm{ZnO}$ sensor showed $8 \%$ sensing response and at 60 $\mathrm{ppm}$, the sensing response reached $35 \%$. During the gas sensing response measurement, the sensor is at a stable position until $60 \mathrm{~s}$ and gas is entered at 60 th $\mathrm{s}$, as shown in the figure, represented by "Gas IN". The equilibrium reaction lasts for about $100 \mathrm{~s}$, before opening the chamber as shown in the figure, represented by "Gas OUT". As the ethanol concentration is diluted, the resistance value will slowly return to the original state. The response time is seen to be $15 \mathrm{~s}$ for the gas reaction equilibrium. The sensor's response time is $\sim 15 \mathrm{~s}$.

The selectivity of the Au doped $\mathrm{ZnO}$ sensor is tested with 4 different gases, along with Ethanol gas. Gas sensing response curves of the gases such as Ethanol, $\mathrm{CO}, \mathrm{NO}_{2}$ and $\mathrm{NH}_{3}$ are shown in Figure 9a. The sensing response of all gases are taken at the same gas concentration, which is $60 \mathrm{ppm}$. Ethanol gas has sensitivity over other selected gases. Figure $9 \mathrm{~b}$ shows the gas sensing response values of the gases, which are Ethanol, $\mathrm{NH}_{3}, \mathrm{CO}$, and $\mathrm{NO}_{2}$. While ethanol has $35 \%$ sensing response, $\mathrm{NH}_{3}$ gas has $5 \%, \mathrm{CO}$ gas has $4.4 \%$, and $\mathrm{NO}_{2}$ gas has $3 \%$ sensing responses.
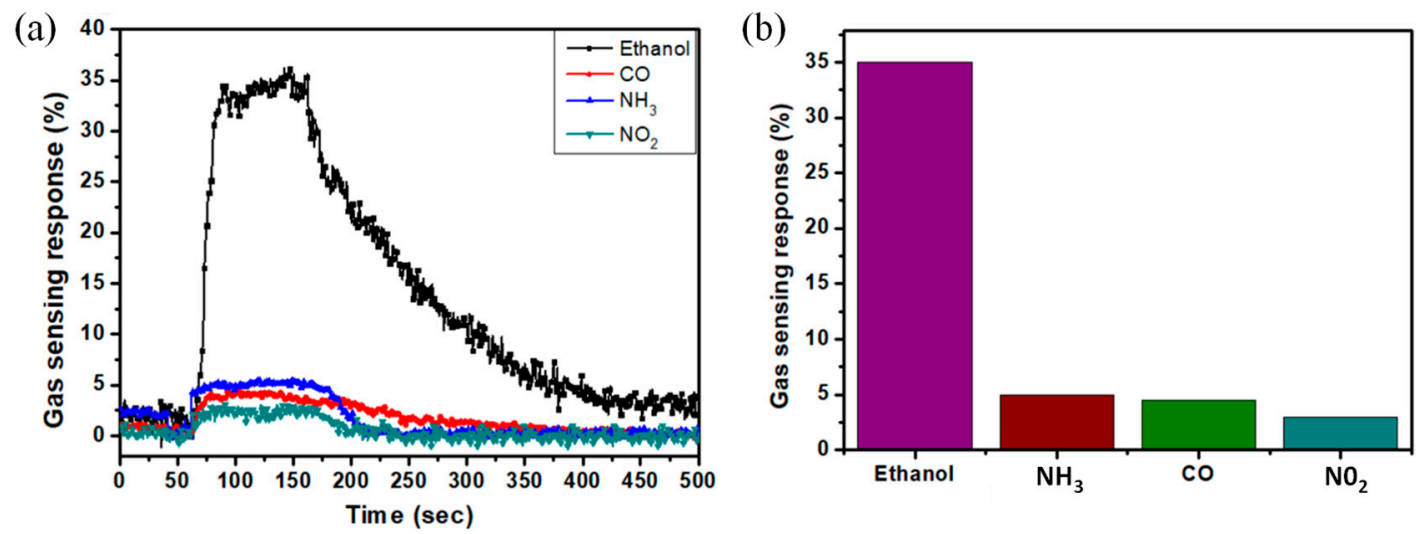

Figure 9. (a) Sensing response of $\mathrm{ZnO}$ sample sensor and (b) $\mathrm{Au}-\mathrm{ZnO}$ sample sensor.

The graph between gas concentration and sensing response is shown in Figure 10. The graph indicates the constant increase in the gas sensing response of both the $\mathrm{ZnO}$ and $\mathrm{Au}-\mathrm{ZnO}$ sensors. For $\mathrm{ZnO}$ sensor, gas sensing response started at $4 \%$ for $15 \mathrm{ppm}$ and reached $20 \%$ for $60 \mathrm{ppm}$. For the 
$\mathrm{Au}-\mathrm{ZnO}$ sensor, gas sensing response started at $8 \%$, which increased by $4 \%$ when compared to the $\mathrm{ZnO}$ sensor and reached $35 \%$ for $60 \mathrm{ppm}$, which increased by $15 \%$ when compared to the $\mathrm{ZnO}$ sensor.

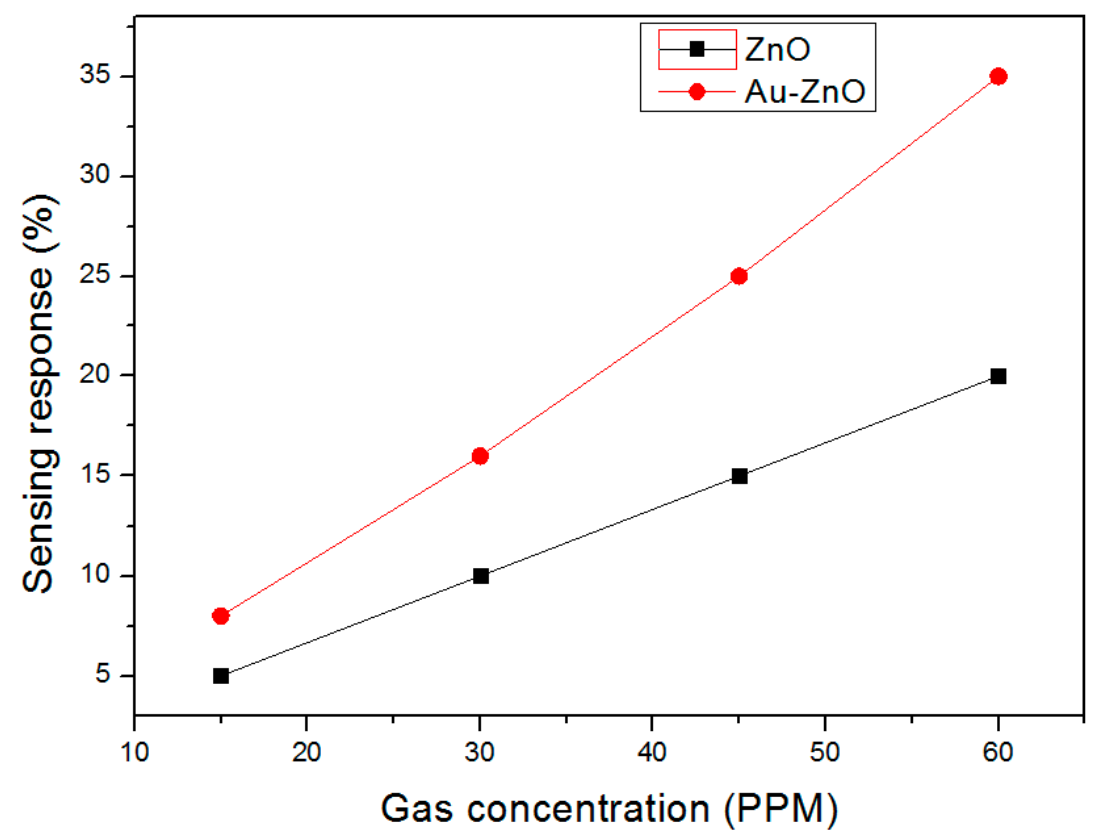

Figure 10. Gas concentration vs. sensing response graph.

\section{Gas Sensing Mechanism}

The sensing mechanism for the metal oxide semiconductors occurs due to the change in the resistance which happens due to the interaction of gas molecules and sensing material. $\mathrm{ZnO}$ is an n-type semiconductor which contains free electrons, and when the $\mathrm{ZnO}$ is treated with Au doping, free electrons from $\mathrm{Au}$ are released into the $\mathrm{ZnO}$ structure and the number of free electrons will be more in the case of $\mathrm{Au}$ doped $\mathrm{ZnO}$. The loss of free electrons leads to formation of $\mathrm{Au} A \operatorname{Anion}\left(\mathrm{Au}^{+}\right)$. As shown in Figure 11a, When the $\mathrm{ZnO}$ sensor is exposed to air, Oxygen will react with the available free electrons and forms Oxygen ions like $\mathrm{O}^{-}, \mathrm{O}^{2-}$, and $\mathrm{O}_{2}{ }^{-}$. The reactions are explained as follows [26]:

$$
\begin{gathered}
\mathrm{O}_{2} \text { (gas) } \rightarrow \mathrm{O}_{2} \text { (ads) } \\
\mathrm{O}_{2} \text { (ads) }+\mathrm{e}^{-} \rightarrow \mathrm{O}_{2}^{-} \text {(ads) } \\
\mathrm{O}_{2}^{-} \text {(ads) }+\mathrm{e}^{-} \rightarrow 2 \mathrm{O}^{-} \text {(ads) } \\
\mathrm{O}^{-} \text {(ads) }+\mathrm{e}^{-} \rightarrow \mathrm{O}^{2-} \text { (ads) }
\end{gathered}
$$

After the formation of Oxygen ions, there will be a formation of depletion layer around the $\mathrm{ZnO}$ material due to the flow of electrons from $\mathrm{ZnO}$ to the formation of Oxygen ions on the surface of the structure. The resistance of the sensor will be increased due to the formation of a depletion layer and the reduction of conductive cross-sectional area. In the presence of a reduction gas like ethanol, the Oxygen molecules react with the ethanol, which releases the free electrons back to the $\mathrm{ZnO}$ structure as shown in Figure 11b. When free electrons migrate back to the AZO structure, the depletion layer decreases and increases the conduction cross-sectional area, which in turn reduces the sensor resistance. The reaction of ethanol with oxygen ions are as follows:

$$
\begin{aligned}
& \mathrm{C}_{2} \mathrm{H}_{5} \mathrm{OH} \text { (gas) }+3 \mathrm{O}_{2}^{-} \text {(ads) } \rightarrow 2 \mathrm{CO}_{2}+3 \mathrm{H}_{2} \mathrm{O}+3 \mathrm{e}^{-} \\
& \mathrm{C}_{2} \mathrm{H}_{5} \mathrm{OH} \text { (gas) }+6 \mathrm{O}^{-} \text {(ads) } \rightarrow 2 \mathrm{CO}_{2}+3 \mathrm{H}_{2} \mathrm{O}+6 \mathrm{e}^{-}
\end{aligned}
$$




$$
\mathrm{C}_{2} \mathrm{H}_{5} \mathrm{OH}(\text { gas })+3 \mathrm{O}^{2-}(\text { ads }) \rightarrow 2 \mathrm{CO}_{2}+3 \mathrm{H}_{2} \mathrm{O}+6 \mathrm{e}^{-}
$$

(a)

\section{In presence of air}

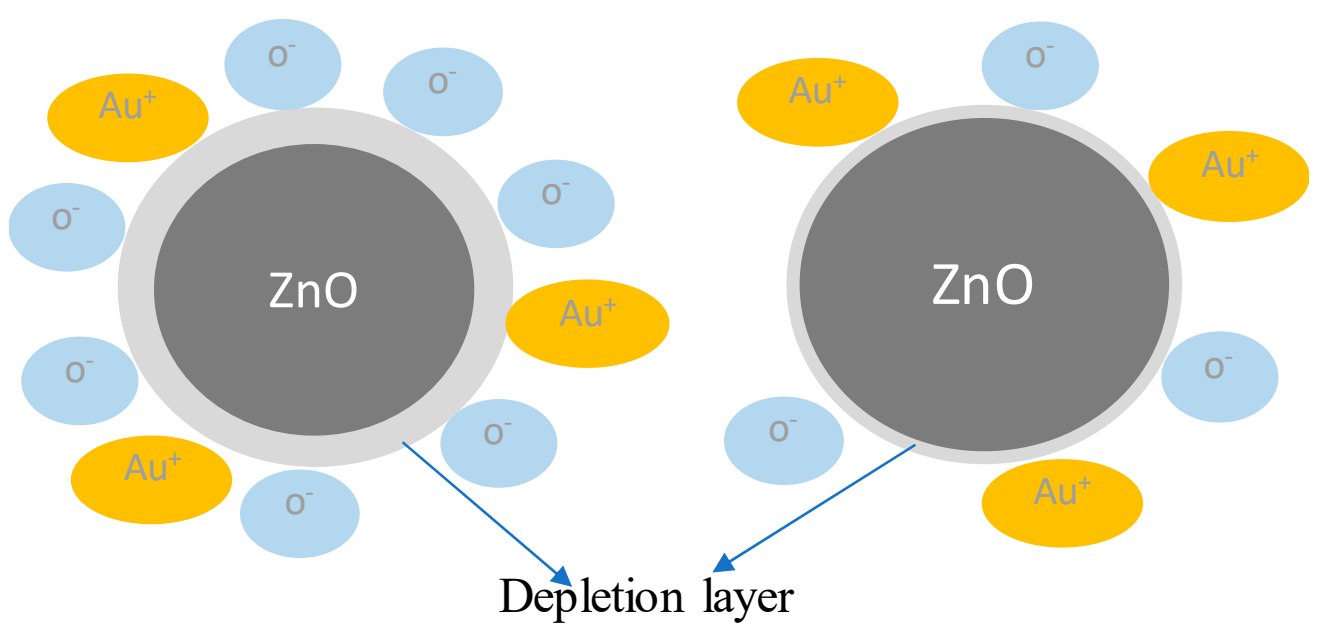

(b)

$$
\text { In presence of ethanol }
$$

Figure 11. (a) AZO sensor in presence of air and (b) in presence of ethanol.

A list of different $\mathrm{ZnO}$ nanostructures and other materials for the ethanol gas sensing is shown in Table 1. From the table, almost all of the studies have used ethanol gas concentration to be more than $100 \mathrm{ppm}$. Flower $\mathrm{NiO} / \mathrm{ZnO}$ sensing material with $100 \mathrm{ppm}$ has the $44 \%$ sensing response which is highest among the list, and the branch $\mathrm{ZnO} / \mathrm{NiO}$ structure has a $6.7 \%$ sensing response at $50 \mathrm{ppm}$. In the current study, Au doped $\mathrm{ZnO}$ showed a 35\% sensing response at $60 \mathrm{ppm}$ ethanol gas concentration, which proved a better sensing material than all of the mentioned study literatures. Since one of the main concerns in preparing a gas sensor is to be able to detect gases at low concentration, our study shows $\mathrm{Au}$ doped $\mathrm{ZnO}$ prepared by hydrothermal synthesis proves to be a better gas sensor.

Table 1. Comparison of ethanol gas sensing response from different literature work and current study.

\begin{tabular}{ccccc}
\hline Sensing Material & $\begin{array}{c}\text { Ethanol } \\
\text { Concentration }\end{array}$ & $\begin{array}{c}\text { Operating } \\
\text { Temperature }\end{array}$ & $\begin{array}{c}\text { Gas Sensing } \\
\text { Response }\end{array}$ & References \\
\hline ZnO nanoplates & $400 \mathrm{ppm}$ & $350^{\circ} \mathrm{C}$ & $23.3 \%$ & {$[27]$} \\
$\mathrm{ZnO}$ nanoflowers & $400 \mathrm{ppm}$ & $350^{\circ} \mathrm{C}$ & $30.4 \%$ & {$[27]$} \\
Hollow $\mathrm{MoO} 3$ & $200 \mathrm{ppm}$ & $350{ }^{\circ} \mathrm{C}$ & $42 \%$ & {$[28]$} \\
$3 \mathrm{D}$ flower $\mathrm{NiO}$ & $400 \mathrm{ppm}$ & $300^{\circ} \mathrm{C}$ & $34 \%$ & {$[29]$} \\
$\mathrm{Ag}$ doped $\mathrm{ZnO}$ & $200 \mathrm{ppm}$ & $320^{\circ} \mathrm{C}$ & $32.8 \%$ & {$[30]$} \\
$\mathrm{Fe}$ doped $\mathrm{NiO}$ & $200 \mathrm{ppm}$ & $320^{\circ} \mathrm{C}$ & $21 \%$ & {$[31]$} \\
Branch $\mathrm{ZnO} / \mathrm{NiO}$ & $50 \mathrm{ppm}$ & $400^{\circ} \mathrm{C}$ & $6.7 \%$ & {$[32]$} \\
Flower $\mathrm{NiO} / \mathrm{ZnO}$ & $100 \mathrm{ppm}$ & $300^{\circ} \mathrm{C}$ & $44 \%$ & This study \\
Au doped $\mathrm{ZnO}$ & $60 \mathrm{ppm}$ & $300^{\circ} \mathrm{C}$ & $35 \%$ & \\
\hline
\end{tabular}

\section{Conclusions}

An Au doped $\mathrm{ZnO}$ structure is successfully prepared with hydrothermal synthesis. The structural properties of a $\mathrm{ZnO}$ structure and $\mathrm{Au}$ doped $\mathrm{ZnO}$ are tested and analyzed, such as XRD analysis, SEM and TEM images, and EDS spectrum. Results showed the crystalline properties of the $\mathrm{ZnO}$ and $\mathrm{Au}-\mathrm{ZnO}$ structure. To test the gas sensitivity, MEMS microheater is prepared and the thermal properties have been studied. The gas sensing results have showed that Au doped $\mathrm{ZnO}$ has a 35\% gas sensing response at 60 ppm ethanol gas concentration, while pure $\mathrm{ZnO}$ has a $20 \%$ gas sensing response at $60 \mathrm{ppm}$. The comparative study of ethanol gas sensing is shown in Table 1. From the literature study, our current work showed great sensing response with less than $100 \mathrm{ppm}$ at $300{ }^{\circ} \mathrm{C}$. 
Author Contributions: Conceptualization Y.N. and Y.-J.H.; methodology Y.N.; experimental process Y.N.; formal analysis Y.N. and Y.-J.H.; writing and original draft Y.N.; re-writing and editing Y.-J.H. and Y.N. All authors have read and agreed to the published version of the manuscript.

Funding: This work was financially supported by the Ministry of Science and Technology of Taiwan, with project numbers: MOST 109-2622-E-218-002-CC2 and MOST 109-2221-E-218-003.

Acknowledgments: The authors would like to thank the Taiwan Semiconductor Research Institute (TSRI) for the processing of the MEMS devices, which were used in this study, and Hui-Jung Shih with the Instrument Center of National Cheng Kung University for supporting the use of a high-resolution SEM (Hitachi SU8000).

Conflicts of Interest: The authors declare no conflict of interest.

\section{References}

1. Flammini, A.; Depari, A. Advanced interfaces for resistive sensors. In Smart Sensors and MEMs; University of Brescia: Brescia, Italy, 2018; pp. 171-219.

2. Kumar, B.; Rajita, G.; Nirupama, M. A Review on capacitive-type sensor for measurement of height of liquid level. Meas. Control 2014, 47, 219-224. [CrossRef]

3. Hanafi, R.; Mayasari, R.D.; Masmui; Agustanhakri; Raharjo, J.; Nuryadi, R. Electrochemical sensor for environmental monitoring system: A review. AIP Conf. Proc. 2019, 2169, 030007. [CrossRef]

4. Hsiao, Y.J.; Nagarjuna, Y.; Tsai, C.A.; Wang, S.C. High selectivity $\mathrm{Fe}_{3} \mathrm{O}_{4}$ nanoparticle to volatile organic compound (VOC) for MEMS gas sensors. Mater. Res. Express 2020, 7, 065013. [CrossRef]

5. Maekawa, T.; Tamaki, J.; Miura, N.; Yamazoe, N.; Matsushima, S. Development of $\mathrm{SnO}_{2}$-based ethanol gas sensor. Sens. Actuators B Chem. 1992, 9, 63-69. [CrossRef]

6. Yamazoe, N. New approaches for improving semiconductor gas sensors. Sens. Actuators B Chem. 1991, 5, 7-19. [CrossRef]

7. Wan, Q.; Li, Q.H.; Chen, Y.J.; Wang, T.H.; He, X.L.; Li, J.P.; Lin, C.L. Fabrication and ethanol sensing characteristics of $\mathrm{ZnO}$ nanowire gas sensors. Appl. Phys. Lett. 2004, 84, 3654. [CrossRef]

8. Hermida, I.D.P.; Wiranto, G.; Hiskia; Nopriyanti, R. Fabrication of $\mathrm{SnO}_{2}$ based $\mathrm{CO}$ gas sensor device using thick film technology. J. Phys. Conf. Ser. 2016, 776, 012061. [CrossRef]

9. Kim, B.J.; Song, I.G.; Kim, J.S. $\mathrm{In}_{2} \mathrm{O}_{3}$-based micro gas sensor for detecting $\mathrm{NO}_{x}$ gases. Electron. Mater. Lett. 2014, 10, 509-513. [CrossRef]

10. Alqahtani, M.M.; Ali, A.M.; Harraz, F.A.; Faisal, M.; Ismail, A.A.; Sayed, M.A.; Al-Assiri, M.S. Highly sensitive ethanol chemical sensor based on novel Ag-doped MESoporous $\alpha-\mathrm{Fe}_{2} \mathrm{O}_{3}$ prepared by modified sol-gel process. Nanoscale Res. Lett. 2018, 13, 157. [CrossRef]

11. Sisman, O.; Poli, N.; Zappa, D.; Comini, E. Synthesis of nanoporous $\mathrm{TiO}_{2}$ with the use of diluted hydrogen peroxide solution and its application in gas sensing. Coatings 2019, 9, 681. [CrossRef]

12. Pronin, I.; Yakushova, N.; Averin, I.; Karmanov, A.; Moshnikov, V.; Dimitrov, D. Investigation of gas-sensitive properties of thin-film thermovoltaic sensor elements based on zinc oxide. Coatings 2019, 9, 693. [CrossRef]

13. Laurenti, M.; Valentina, C. Porous zinc oxide thin films: Synthesis approaches and applications. Coatings 2018, 8, 67. [CrossRef]

14. Wu, W.Y.; Ting, J.M.; Huang, P.J. Electrospun $\mathrm{ZnO}$ nanowires as gas sensors for ethanol detection. Nanoscale Res. Lett. 2009, 4, 513-517. [CrossRef]

15. Sahay, P.P.; Tewari, S.; Jha, S.; Shamsuddin, M. Sprayed ZnO thin films for ethanol sensors. J. Mater. Sci. 2005, 40, 4791-4793. [CrossRef]

16. Maziarz, W.; Rydosz, A.; Pisarkiewicz, T.; Domanski, K.; Grabiec, P. Gas-sensitive properties of ZnO nanorods/nanowires obtained by electrodeposition and electrospinning methods. Procedia Eng. 2012, 47, 841-844. [CrossRef]

17. Kim, S.W.; Shizuo, F.; Shigeo, F. ZnO nanowires with high aspect ratios grown by metalorganic chemical vapor deposition using gold nanoparticles. Appl. Phys. Lett. 2005, 86, 153119. [CrossRef]

18. Aliahmad, M.; Dehbashi, M. Ni-doped $\mathrm{SnO}_{2}$ nanoparticles synthesized by chemical Co-precipitation method. Iran. J. Energy Environ. 2013, 4, 49-52. [CrossRef]

19. Cao, L.; Kiely, J.; Piano, M.; Luxton, R. A Copper oxide/zinc oxide composite nano-surface for use in a biosensor. Materials 2019, 12, 1126. [CrossRef] 
20. Hjiri, M.; Mir, L.E.; Leonardi, S.G.; Pistone, A.; Mavilia, L.; Neri, G. Al-doped ZnO for highly sensitive CO gas sensors. Sens. Actuators B Chem. 2014, 196, 413-420. [CrossRef]

21. Deshwal, M.; Arora, A. Enhanced acetone detection using Au doped $\mathrm{ZnO}$ thin film sensor. J. Mater. Sci. Mater. Electron. 2018, 29, 15315-15320. [CrossRef]

22. Li, Y.; Zhang, L.B.; Song, S.; Lian, X.X. Enhanced acetone-sensing performance of Au/Y-ZnO composite prepared using a facile wet chemical method. J. Electron. Mater. 2020, 49, 8. [CrossRef]

23. Lai, T.Y.; Fang, T.H.; Hsiao, Y.J.; Chan, C.A. Characteristics of Au-doped $\mathrm{SnO}_{2}-\mathrm{ZnO}$ heteronanostructures for gas sensing applications. Vacuum 2019, 166, 155-161. [CrossRef]

24. Huang, J.; Zhou, J.; Liu, Z.; Li, X.; Geng, Y.; Tian, X.; Du, Y.; Qian, Z. Enhanced acetone-sensing properties to ppb detection level using Au/Pd-doped ZnO nanorod. Sens. Actuators B Chem. 2020, 310, 127-129. [CrossRef]

25. Tong, W.; Wang, Y.; Bian, Y.; Wang, A.; Han, N.; Chen, Y. Sensitive cross-linked $\mathrm{SnO}_{2}: \mathrm{NiO}_{\text {networks for mems }}$ compatible ethanol gas sensors. Nanoscale Res. Lett. 2020, 15, 35. [CrossRef]

26. Zhu, L.; Zeng, W.; Yang, J.; Li, Y. One-step hydrothermal fabrication of nanosheet assembled NiO/ZnO microflower and its ethanol sensing property. Ceram. Int. 2018, 44, 19825-19830. [CrossRef]

27. Zhu, L.; Li, Y.; Zeng, W. Hydrothermal synthesis of hierarchical flower-like ZnO nanostructure and its enhanced ethanol gas-sensing properties. Appl. Surf. Sci. 2018, 427, 281-287. [CrossRef]

28. Zhu, L.; Zeng, W.; Li, Y.; Zhang, $\mathrm{H}$. Novel hollow $\mathrm{MoO}_{3}$ cage structure and its gas sensing property. Mater. Lett. 2018, 229, 269-271. [CrossRef]

29. Wang, J.; Zeng, W.; Wang, Z. Assembly of 2D nanosheets into 3D flower-like NiO: Synthesis and the influence of petal thickness on gas-sensing properties. Ceram. Int. 2016, 42, 4567-4573. [CrossRef]

30. Umar, A.; Khan, M.A.; Kumar, R.; Algarni, H. Ag-Doped ZnO nanoparticles for enhanced ethanol gas sensing application. J. Nanosci. Nanotechol. 2018, 18, 3557-3562. [CrossRef] [PubMed]

31. Li, X.Q.; Wei, J.Q.; Xu, J.C.; Jin, H.X.; Jin, D.F.; Peng, X.L.; Hong, B.; Li, J.; Yang, Y.T.; Ge, H.L.; et al. Highly improved sensibility and selectivity ethanol sensor of mesoporous Fe-doped NiO nanowires. J. Nanopart. Res. 2017, 19, 396. [CrossRef]

32. Kaur, N.; Zappa, D.; Ferroni, M.; Poli, N.; Campanini, M.; Negrea, R.; Comini, E. Branch-like NiO/ZnO heterostructures for VOC sensing. Sens. Actuators B Chem. 2018, 262, 477-485. [CrossRef]

33. Wang, C.; Zeng, W.; Chen, T. Facile synthesis of thin nanosheet assembled flower-like NiO-ZnO composite and its ethanol-sensing performance. J. Mater. Sci. Mater. Electron. 2016, 28, 1-6. [CrossRef] 